\title{
The Nexus between Energy pricing, Investment Financing and Economic Growth in Nigeria
}

\author{
Edame, Greg Ekpung, Ph.D. \\ Department of Economics, Faculty of Social Sciences, University of Calabar, Calabar - Nigeria \\ Email: gregedame@yahoo.com, Phone:+2348038972991 \\ Effiong, Charles E. (Ph.D Candidate) \\ Department of Economics, Faculty of Social Sciences, University of Calabar,Calabar-Nigeria \\ Email: dodosky01@yahoo.com, Phone:+2348034437978

\begin{abstract}
Adaba, Glory Agatha
Department of Public Policy and Administrative Studies, Institute of Public Policy and Administration, University of Calabar, Calabar-Nigeria

Email: aadabaglory@yahoo.com, Phone:+2348133974693
\end{abstract} \\ Uwoghiren, Bright Osas \\ Department of Public Administration, Faculty of social Sciences, \\ University of Calabar, Calabar-Nigeria. \\ Email: osasese05@yahoo.com, Phone: +2348060823406
}

Doi:10.5901/mjss.2014.v5n4p215

\begin{abstract}
This paper attempted to descriptively analyze the nexus between energy pricing and investment finance as it relates to other potential economic variables required for the transformation of the Nigerian economy. The paper also make a comparative analysis of how such chosen macroeconomic variables such as FDI, HCl, Public investment, RGDP, Private investment, etc behave before and after democracy to determine the period where energy pricing, investment and financing and other macroeconomic variables impacted positively on the economy as a means of enhancing the standard of living of the ordinary Nigerian, their health status, infrastructural facilities like power etc. The study also uses the Error Correction Method(ECM) for analyzing the relationship among this macroeconomic variables to find out if there is a positive or negative unidirectional causal nexus from energy pricing, investment and finance. While a negative unidirectional nexus exist from inflation and the rate of interest, hence the result shows that energy pricing impacts positively on investment and finance. However, recommendations has been proffer for policy makers and the stakeholders, which if adequately implementated will enhance efficient and effective management of Nigeria energy and investment finance with the broad aim of transforming the economy and positioning it for global relevance.
\end{abstract}

Keywords: Energy pricing, Investment, Finance, National development.

JEL Classification: 013, 016,021,044,054

\section{Introduction}

In any economy both developed and developing the discovery of oil is always marked with serious celebration heralding the advent of economic growth and development due to the anticipated flow of revenue from this sector. This huge revenue if adequately utilize can put the economy in a global map as the most developed oil producing nations of the world.

Although, the advent of oil in Nigeria has been both a blessing and curse to the Nigerian economy. Oil brought with it much revenue and this was seen as a blessing to the economy, because it enhanced the economic growth and development of the country. Various regimes (starting from the 1970's) were able to undertake many development projects that would otherwise not have been possible. The oil sector provided jobs for people; manpower development 
was engaged in, Nigerian foreign earning as enhanced etc. These gains notwithstanding, some negative impact of oil were also felt by the economy over the years. In recent times, our leaders have enhanced this negative effect through their quest to meet their selfish interest amassing wealth.

For more than five decades since oil was discovered and exploited in Nigeria, the country's economic policy formulations have entirely been embedded in this single resource of nature, thereby making Nigeria depend solely and vulnerable to international oil price booms and bursts. The paradox of plenty used to describe the Nigerian oil sector development is the relationship between resource abundance and bad economic policies, underdevelopment, poverty and conflict prevalence in most oil rich countries. The presence of oil or minerals gives rise to rent seeking and corruption, which adversely affect the climate for investment and growth. But the deeper sense in which natural resources impede the development of institution is that they minimize the two-way interactions between the state and its citizens hereby causing social unrest and communal conflict.

As observed by Basedau (2005), natural resource generate a paradox of plenty when they create dependence and damage other tradable sectors and sources of economic growth and development such as human capital and the manufacturing sector. It can also stimulate unwise economic policies such as import substitution policy which prevent efficient and effective investments of rents and make the economy vulnerable to external shocks caused by declining terms of trade as natural resources exhibit lower income elasticity of demand than manufactured products. Nigeria seems to be a prime example of the curse that natural resources can bring (collier / Hoeffler 2001: le Billion 2001; Auty 1993 Sachs / Warner 2001). Indeed 50 years of substantial oil production have not resulted in substantial socioeconomic development in the country. The poverty rate today is extremely high, with 50 percent of the population living on less than US $\$ 1$ per days. In fact the current poverty level exceeds that of the period before the first oil boom in the 1970s, which has a little above 35 percent. The National social and transport infrastructure is in a desolate condition, and the country is marked by chronic internal instability and periodic flare-ups of violent conflict both in the north (Bokoharam) and in the South Movement for the Emancipation of Niger Delta (MEND).

The Nigerian Economy has grossly underperformed relative to her enormous resources endowment and her peer nations. The cost of petrol has increased from N65 per liter to N97 per liter. This makes Nigeria the most expensive place to buy petrol in any oil producing nation. It has the $6^{\text {th }}$ largest gas reserves and the $8^{\text {th }}$ largest crude oil reserves in the world and yet one of the impediments of the power sector is inadequate gas supply. It is endowed in commercial quantities with about 37 solid minerals types and has a population of over 159 million persons; yet economic performance has been rather weak and does not reflect these endowments.

If compared with the emerging Asian countries notably; Thailand, Malaysia, China, India and Indonesia that were far behind Nigeria in terms of GDP per capital in 1970, these countries have transformed their economies and are not only miles ahead of Nigeria, but are also major players on the global economic arena (Sanusi, 2010). Indeed, Nigeria's poor economic performance particularly in the last forty years is better illustrated when compared with china which now occupies our envlable position as the second longest economy in the world. In 1970, while Nigeria had a GDP per Capita of US 233.35 and was ranked $88^{\text {th }}$ in the world, china was ranked $114^{\text {th }}$ with a GDP per capita of US\$111.82.

Despite the huge revenue from oil, it can be said that Nigeria is suffering heavily from the resource curse malady. For most Nigerians, a multi-billon dollar oil industry is a mixed blessing at best, and nothing more than a fairy tale as a result of political instability, lack of focused and visionary leadership, economic mismanagement and corruption. Although statistical evidence (CBN, 2009) has shown that about $82 \%$ of Nigeria's revenue accrued from oil export, opinions differs on the impact of such huge revenue from oil on the economy due to the high level of insecurity corruption, dilapidated infrastructure, epileptic power supply and near total neglect of other vital sectors of the economy as a result of mismanagement of the oil wealth.

This paper therefore using secondary data, presents a descriptive analyses of Nigeria's economic performance before and after democracy to reveal how the economy faired during this two periods and suggest the way forward for economic development and growth. Hence, the paper is divided into four sections, section one is the introductory part, section two is the literature review and theoretical issues, and section three handles the methodology and analysis of data while the last section is concern with summary and conclusion of the work.

\section{Literature Review and Theoretical Issues}

\subsection{Literature review}

With regard to energy pricing, Ayadi (2005) examined the relationship between oil price changes and economic 
development in Nigeria. The study however employed a multivariate VAR model with oil price, exchange rate (weighted), the natural logarithm of many supply, short-term interest rate (discount rate), the consumer price index and the industrial production index as the variables of interest, and estimates. This VAR model on the quarterly data over the period 1980:1-2004:1. Identification is carried out through the orthogonal zed choleski decomposition. Applying variance decomposition technique, the study revealed that industrial output volatility is through the impact of oil price on the exchange rate and that oil price increase itself is not a significant factor in promoting the industrial development. The study however concluded that the discovery, of oil has been a curse rather than a blessing.

Furthermore, Olomola and Adijumo (2006) examining the effect of oil price shock on output, inflation, the real exchange rate and the many supply in Nigeria using quarterly data from 1970 to 2003. The Vector Autoregressive (VAR) method of analysis was employed to analyse the data. The findings of the study were contrary to those of other countries. It was observed that oil price shock does not affect output and inflation in Nigeria. However, oil price shocks do significantly, influence the real exchange rates. The implication of the study's findings is that a high real oil price may give rise to wealth effect that appreciates the real exchange rate which may consequently squeezed the tradable sector, giving rise to the Dutch Disease.

The oil industry in Nigeria has been exploring and producing oil for about five decades. During these periods or decades, roughly 1,668 producing wells were in existence out of which 1,056 is on land/swamp and 630 is offshore and they both provide for the country about 2.5 million barrels of crude oil daily. Eromosole (1997) in his study posited that the oil industry in Nigerian National Petroleum Corporation covers all firm engaged in exploitation and production of crude oil and natural gas, in refining and distribution of petroleum product and petro-chemical manufacturing. He said that participants and activities in the oil industry are usually categorized into upstream and downstream sectors. Upstream activities are related to oil and gas exploration and production while downstream activities are related to the transportation and transformation into finished products of oil and gas and their derivations.

The exploration and production activities have witnessed significant development since the first oil explorers in Nigeria. A number of incentives have been extended to producing companies. For example, in ten years to 1986, NNPC drilled more than 60 wells with an average success rate of six in ten; a result which is capable to what is obtained in technologically advanced countries' (Duke 1995). Agbah (1997) indicated that for many years, Nigeria enjoyed the status of the cheapest gasoline in the world, a status the citizenry was not in a hurry to drop. Many argued that the status was artificially created by the massive depreciation and devaluation of the local currency (Naira). This followed the implementation of structural Adjustment programmed (SAP) in the late eighties. Only one sixth of Nigerian's oil production is earmarked for local consumption, the balance being exported at international price (Eromosele, 1997).

The handling of oil export in Nigeria is nationally prescribed and therefore, it is the primary determinant of Nigerians national economic performance, the welfare of its citizens and indeed the states of the nation. As a result of this, crude oil marketing must be conducted with a sense of purpose and missionary dedication. To buttress this point Emenuga (1993) opined that Nigerian's earnings from oil went up from just N8.8 million in 1960 to N4.733 million in 1975 and N8880.8 Million in 1979. According to him, the so-called oil boom arrived with its windfalls. Thus as the Country's oil wealth was expanding rapidly, the traditional exploits of the country such as groundnut, cocoa, and palm produce were rapidly approaching their vanishing points. Indeed, most sectors of the economy were not healthy at this point in time and would have been because they were just emerging from the ravages of the thirty-month civil war and were still undergoing reconstruction and rehabilitation.

Olashore (1989) further pointed out that one of the most discomforting shortcoming of contemporary Nigeria has been the total neglect and non-commercialization of the abundant natural gas resources, a resource which through careful planning and development could turn the economy around and possibly propel us into another era of boom. Natural oil gas has been used commercially as a fuel for over 150 years in America and for centuries in China. The production and distribution of the gas has become an important segment of most economies in both the developed and developing world.

According to Petters (2005), as oil exporting third world nation, Nigeria's economic development has witnessed trials and tribulations, as the nation's fortunes have risen and fallen in the stormy seas of the international oil market. Nigeria's vulnerability to oil price shocks stems from the nations over dependence on crude oil export. This is amply evident from the drastic decline in non-oil exports over the past three decades of oil production in Nigeria. Crude oil accounted for 7.1 percent of total exports in 1961, which was dominated at that time by Cocoa, groundnut and rubber in that order. In 1965, oil had climbed to 13.5 percent of the nation's export earnings, and by 1970 it had become the leading source of foreign exchange, accounting for 63.9 percent. The 1973 Arab oil embargo against the United States of America did not only earn Nigeria the windfall revenue of oil boom but made the country popular in international arena. 
By 1979, Oil sales had completely over-shadowed non-oil exports, as it then contributed about 95 percent 0 the country's exports earnings. During the peak of the oil boom, Nigeria's premium crude, the Bonny Light (37 API), fetched the commanding price of 40 dollars a barrel. Antai (2007) maintained that Nigeria is one of the countries where the price of its domestic oil has been on the increase since 1970s. This is in spite of the fact that Nigeria in addition to heavily four major oil refineries also imports refined products to satisfy its domestic consumption.

The crisis in the downstream segment of the Nigerian oil sector has therefore been a Major concern to most people in Nigeria. This is because the constant fuel pump price increase in the country has been traced to the inefficiencies of the nation's refineries in addition to the sabotage from bunkering, oil spillages and attitude of some marketers. The effect of this on the nation's economy is constant fuel supply disruptions leading to both economic and environmental problems. In Nigeria, there is a multiple negative effect of incessant increase in the price of crude oil on the economy. This is because whatever happens in the oil sector affects all other sectors of the economy and by implication, it affects the macro-economic policies of the country and economic performance.

According to IMF survey (2004) the deeper sense in which natural resources impede the development of institutions is that they minimize the two- way interaction between the state and its citizens. Political scientist and economic historians have emphasized this effect. They went further that governments that have easy recourse to oil rents do not need to promote wealth creation that they can subsequently tax; in turn, citizens have less incentive to hold government accountable. In past decades, Nigeria rulers may have plundered oil wealth to the tune of tens of billions of dollars. The explosion in wind fall financed government expenditures and also provided increased opportunities for kickback. All of these factors have contributed to poor growth but also to staggering destructive development outcomes. Thus, oil mismanagement and institutional deterioration that it has led to, has perhaps been the single most important cause of Nigeria's economic and political problems.

Akoma (2010 in vanguard, September, 2010) reported that this cause serious unemployment, industrial crisis, inflation and devaluation of the naira. What we are saying is that once the price of fuel doubles, correspondingly hyperinflation takes over. So since that is known, it is obvious that the government is the one that is deliberately trying to destroy the economy. It is difficult to believe but that is what is happening because deregulation does not make sense as it ranks with SAP if you consider he million of unemployed Nigerians (70 million out of 90 million able bodied men and women) and the poverty level etc.

\subsection{Theoretical issues}

In recent years there has been renewed and increasing interest in the study of natural resources and their diverse international and domestic impacts. Although partly divergent in their main assumptions, the central theoretical approaches focusing on the topic of resource abundance are the rentier state theory and the resource curse thesis both argued that resource exporting countries are negatively affected by political, economic, and social distortions. The concept of the rentier state goes back to Hossein Mahdavy's study of pre-revolutionary Iran (1971). It was particularly expanded upon by Hazem Beblawi and Giacomo Luciani (1987), who classified a rentier state as a state in which at least 40 percent of the total government revenue consists of economic rents.

These rents can be defined as "the excess over return to capital, land and labour when these factors of production are put to their next best use" (Dunning 2008:39). According to the rentier state theory, the two central effects of dependence on economic rents are economic inefficiency and, as a consequence, the obstruction of socioeconomic development (Beck 2007; 46). With regard to the political effects, the rentier state theory proposes that (oil) rents have a stabilizing effect on authoritarian rule (Mahdavy 1971; Beblawi / Luciani 1987; Ross 2001). Initially based on empirical findings in the Middle East, the rentier theory is claimed by its proponents to be universally valid (Black 2007:44). It attributes the linkage between oil rents and authoritarianism to the following causal mechanisms: Firstly, it is presumed that oil rents foster the formation of stabilizing patronage networks, wide spread clientelism, and assistentialistic distribution policies, all of which lesson the pressure from the population to democratize and may additionally result in the depoliticization of the society. Secondly, the abundance of revenues generated by the oil sector means that national rulers do not need to tax the population. This gain may disburden the political elite of demands from the population for political participation and accountability on the part of the elites.

Over the last decade, another theoretical approach the resource curse thesis has gained importance within the theoretical debate on natural resource. Some authors place special emphasis on the economic characteristics of resources rich countries. Building upon the basic assumption of rentier sate theory, they claim that resource wealth is linked to poor economic growth (Auty 1993; Sachs/Warner 2001) and other economic problems such as Dutch disease 
effects and poor performance of the agricultural and manufacturing sectors accompanied by an insufficient degree of diversification and extreme vulnerability towards external shocks. A further branch of the resource course thesis focuses on the link between natural resources and violent conflicts (collier/Hoeffler 2001; le Billion 2001; de soysa 2000).

The central hypothesis- partly contradictory to the rentier state theory's assumptions is that resource dependent countries are more likely to experience internal instability and violent conflict than non-resources countries. The causal mechanisms assumed to be responsible for this link include, on the one hand, the fact natural resources can be the motive for violent conflicts. This means that parts of the population might feel that they are deprived of the financial benefits of the resource revenues while possible also suffering from the ecological and social impacts of production (motive of grievance) or that resource wealth can be the target of avaricious rebels who wish to take possession of the resource revenues (motive of greed) (Collier/Hoffler 2001). On the other hand, resource revenues can serve as a catalyst for violent conflict by financing the rebel groups and other actors involved (opportunity, feasibility) and thus prolonging the conflict (Collier/Hoeffler, 2004).

\section{Methodology and Analysis}

The performance of the Nigerian oil sector with regards to economic growth has been analyzed by different scholars using an econometric approach. However, this study adopts a descriptive approach to examine the trend relationship between oil revenues and some key potentials economic growth drivers. Such analyses are based on secondary data gathered from central Bank of Nigeria publications covering the period 1970 to 2010 though the trend is segmented into two periods; before democracy and the current period of democracy to allow us examine both periods as it relates to the existing poverty level in Nigeria.

Fig. 1: Trend of selected macroeconomic drivers in Nigeria

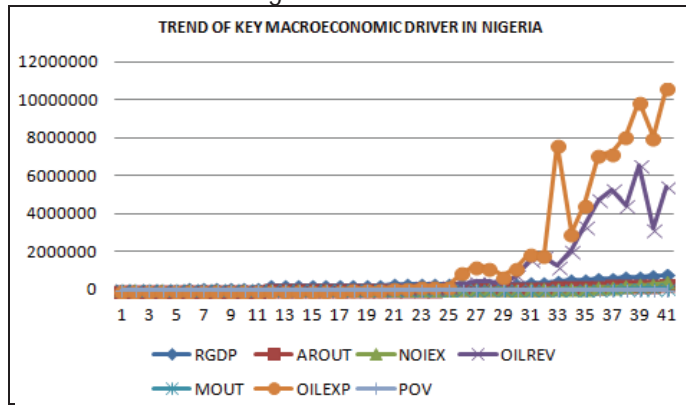

The trend of key potential economic growth variables are compared with the level of poverty in Nigeria between 19792010. The graph revealed that as oil export (OILEXP) increased, oil revenue also increased leaving RGDP (Real Gross Domestic Product), AROUT (Agricultural Output) NOIEX (Non-Oil Export), MOUT (Manufacturing Output), and POV (Level of Poverty)unaffected. This shows that the huge revenue from oil has no meaningful effect on the living standard of an average Nigerian.

Fig. 2: Oil revenue compared with manufacturing output and poverty trend

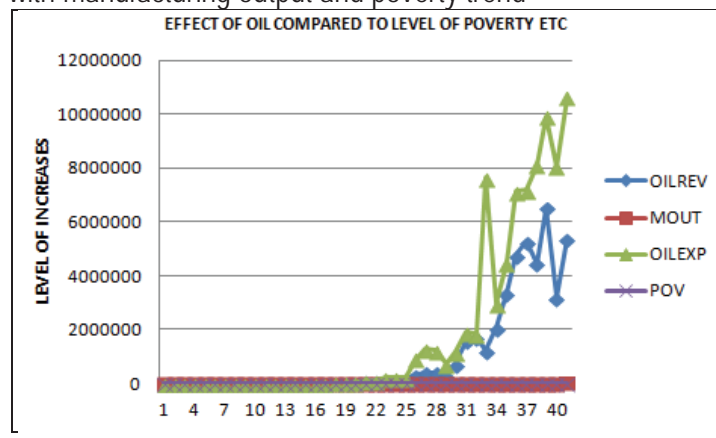


Fig. 3:

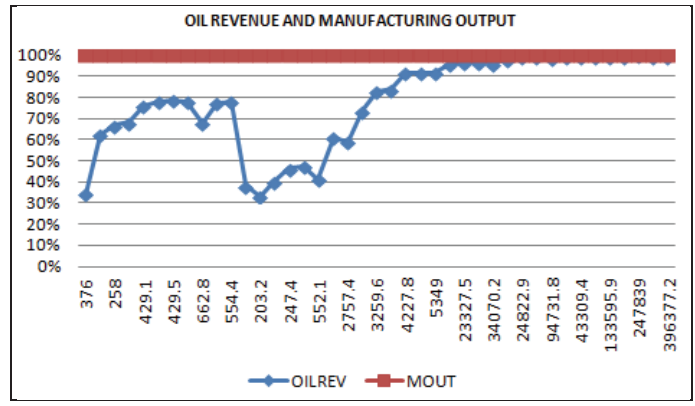

This compared the huge revenue from oil Export with the level of poverty and manufacturing output in the economy as in whole within the period of fourty-one years (1970-2010). However, irrespective of the consistent revenue arising from oil export, the manufacturing output has not benefited from such revenue, due to the high level of corruption associated with the oil sector of the economy (see also fig 3).

Fig. 4: Level of improvement amongst variables

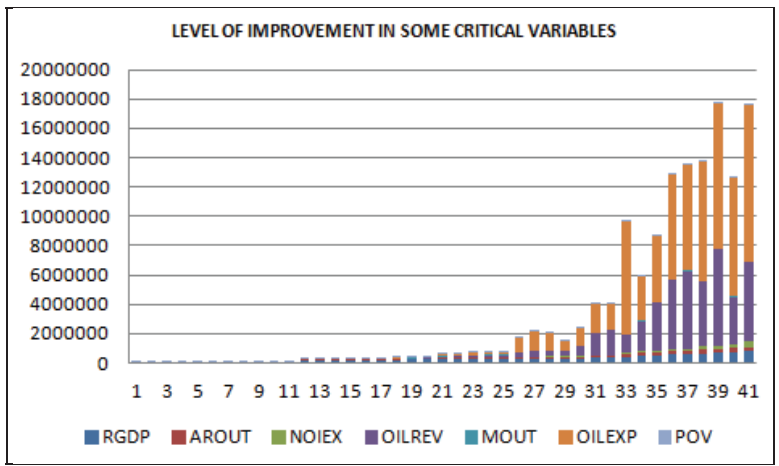

The level of improvement recorded by oil export activities cannot be compared to that of the Non-oil export and Agricultural output even though both has highest potentials for employment opportunities . This depicts the extent of neglect by successive government as a result of the huge revenue generated from the oil sector leading to the neglect of other sectors.

Fig. 5: Poverty level compared with oil export

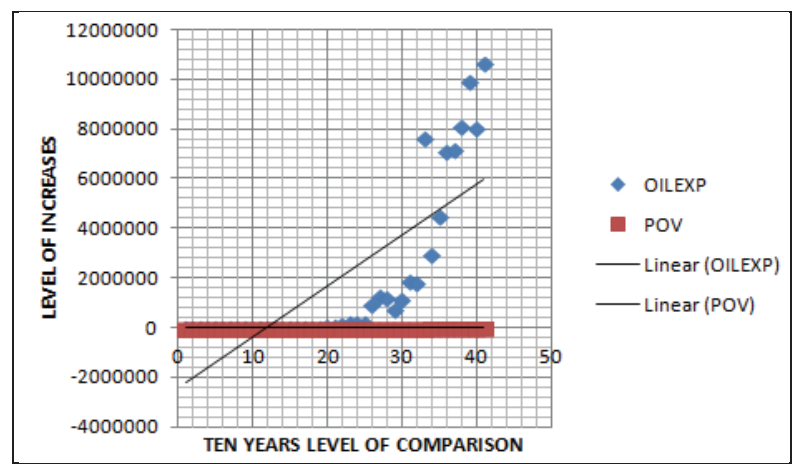


The graph depicts the trend of poverty prevalent in the country despite the huge revenue from oil export in the country. From the graph, while poverty was horizontal and dominant attaining a comfortable position in the country, the level of oil export experienced continuous increase with its associated negative environmental impact on the economy. Such environmental impact also affects the people means of livelihood leading to a poor standard of living as a result of pollution and oil spillage especially in the Niger Delta region.

Fig. 6 and 7: Trend of potential nigeria's economic growth drivers before and during democracy

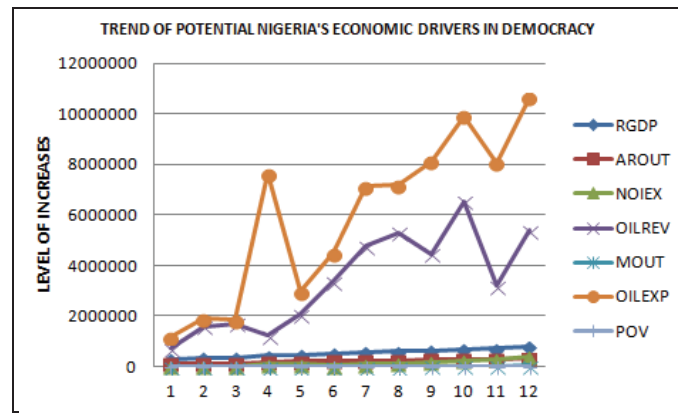

Fig. 7:

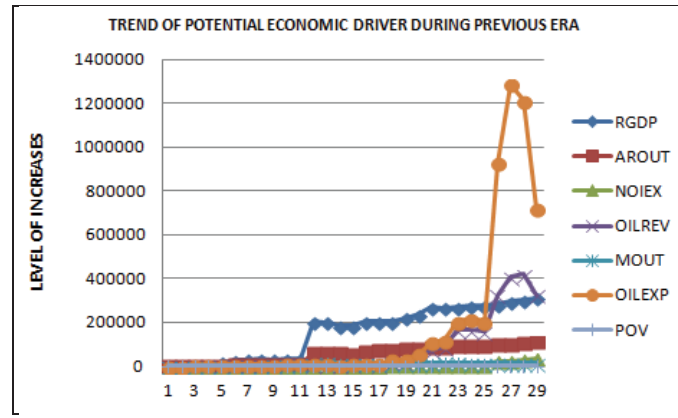

Fig. 6 Showcase the existing trend of Nigeria's potential economic driver's between 1999 and 2010 (the period of Democracy), poverty is included to assess its behaviour within this period of analysis. From the graph, we noticed that oil revenue experienced a continuous growth as well as AROUT, RGDP and NOIEX. Even though the level of increased in these variables were marginal, the steady improvement experienced by them year- in- year- out depicts some level of commitment on the part of the current democratic government. By and large, these variables were near total neglect during the previous Era (Before Democracy) exception of Agricultural output (see Fig 7).

Fig. 8: Poverty level before and during democracy

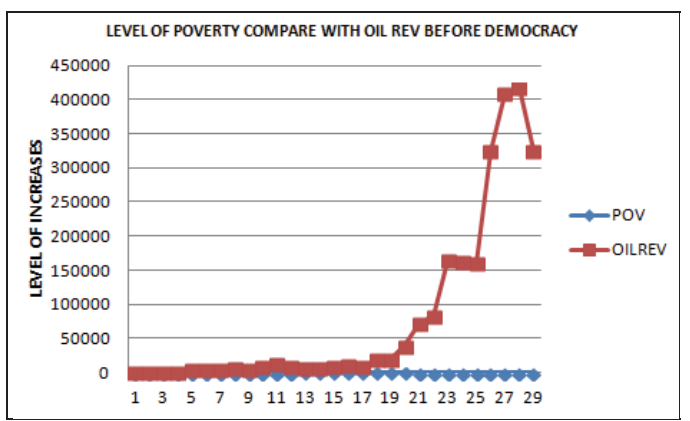


Fig. 9:

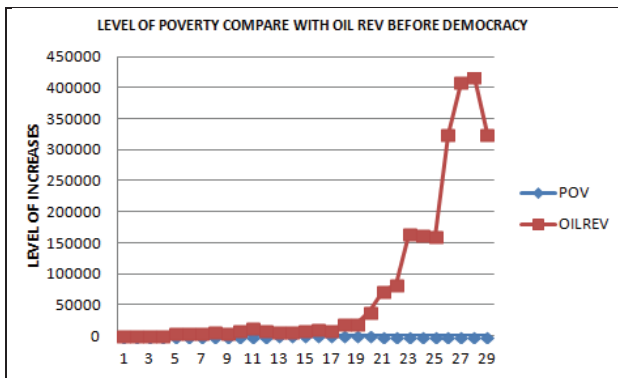

However, oil revenue was steadily on the part of increased while RGDP increased was very slow and low when compared with the level of increased within the period of Democracy. In fig 10 and 11, oil revenue and level of poverty are compared side by side to examine their trend. And it has been noticed that despite the huge oil revenue, the high level of poverty did not experience any meaningful improvement. In the early part of the period1970s when Agriculture was the main source of revenue with minimal oil revenue, the economy seems to have fared better than in the current period of continuous increase in oil revenue.

Table 1: Sectoral Contribution to Real GDP (\%)

Contribution to GDP in (\%)
Agriculture
Solid Mineral
Crude Petroleum \& Natural gas
Manufacturing
Telecommunication \& Post
Finance \& Insurance
Wholesale \& Retail Trade
Building \& Construction
Hotel \& Restaurants
Real Estate
Business \& Other Services
Others

Sources: National Bureau of Statistics

$\begin{array}{clcll}2006 & 2007 & 2008 & 2009 & 2010 \\ 41.72 & 42.01 & 42.13 & 41.70 & 40.84 \\ 0.28 & 0.30 & 0.32 & 0.33 & 0.34 \\ 21.85 & 19.60 & 17.35 & 16.29 & 15.85 \\ 3.91 & 4.03 & 4.14 & 4.17 & 4.16 \\ 1.83 & 2.31 & 2.92 & 3.66 & 4.56 \\ 3.90 & 3.85 & 3.81 & 3.70 & 3.57 \\ 14.95 & 16.18 & 17.41 & 18.14 & 18.70 \\ 1.62 & 1.72 & 1.84 & 1.92 & 2.00 \\ 0.41 & 0.43 & 0.46 & 0.48 & 0.50 \\ 1.47 & 1.55 & 1.63 & 1.69 & 1.74 \\ 0.81 & 0.84 & 0.87 & 0.89 & 0.90 \\ 7.23 & 7.19 & 7.15 & 7.02 & 6.83 \\ 100.00 & 100.00 & 100.00 & 100.00 & 100.00\end{array}$

Table 2: Sectoral Growth Rate (\%)

$\begin{array}{llllll}\text { Sectoral Growth (\%) } & 2006 & 2007 & 2008 & 2009 & 2010 \\ \text { Agriculture } & 7.40 & 7.19 & 6.27 & 5.88 & 5.64 \\ \text { Solid Mineral } & 10.28 & 12.75 & 12.77 & 12.08 & 12.28 \\ \text { Crude Petroleum \& Natural gas } & -4.51 & -4.54 & -6.19 & 0.45 & 4.98 \\ \text { Manufacturing } & 9.39 & 9.57 & 8.89 & 7.85 & 7.64 \\ \text { Telecommunication \& Post } & 33.66 & 33.84 & 34.02 & 34.18 & 34.41 \\ \text { Finance \& Insurance } & 4.98 & 5.03 & 4.82 & 4.01 & 3.95 \\ \text { Wholesale \& Retail Trade } & 15.26 & 15.20 & 14.02 & 11.48 & 11.19 \\ \text { Building \& Construction } & 12.99 & 13.03 & 13.07 & 11.97 & 12.08 \\ \text { Hotel \& Restaurants } & 12.91 & 12.95 & 12.94 & 11.89 & 12.01 \\ \text { Real Estate } & 11.68 & 11.72 & 11.79 & 10.94 & 10.66 \\ \text { Business \& Other Services } & 10.02 & 10.05 & 10.13 & 9.39 & 9.37 \\ \text { Others } & 5.79 & 5.85 & 5.29 & 5.00 & 5.01\end{array}$

Sources: National Bureau of Statistics.

From the table above, Agriculture holds a great potential for the economy if compare to crude petroleum and Natural Gas. It's pertinent to note here that wholesale and Retail Trade Contributed more to Real GDP during the period 2008, 2009 and 2010 compare to crude petroleum and Natural gas. 


\section{Summary and Conclusion}

By and large, Nigeria and Nigerian are not reaping the benefits of their resource due to high level of mismanagement of her resources. The following recommendations is proffer to improve on the oil economy of Nigeria.(1) For the country to maximize the huge revenue derived from oil export, such revenue must be channel towards the development of other critical sectors of the economy e.g. the agricultural and manufacturing sectors. (2) This becomes pertinent as a result of the high employment opportunities inherent in these sectors.

However, the available evidence shows that the economy faired better in the current democratic period than in the previous era's, therefore (3) adequate development strategy is put in place for efficient utilization of revenue accrued from oil export, Nigeria and Nigerian will be better for it and the current trend of poverty will reduce to the barest minimum.(4) The current trend of violence is an attempt to showcase annoyance and displeasure in the management of national wealth amidst widespread poverty. Therefore, (5) all hands must be on deck to ensure oil wealth is efficiently and effectively used to transform the other sectors of the economy in general and the living standard of the masses in particular.

\section{References}

Akoma, E. (2010) Vanguard Newspaper, September 27,Abuja: Nigeria Vanguard Corporations Ltd.

Ayadi, O. F. (2005) Oil and the Macroeconomy: evidence form a monoproduct economy. In A. Adenikinju, A. Iwayemi E. W lledare (Eds), Energy technology and infrastructure for development (Pp. 237-249). Ibadan: Atlantis Books.

Antai, E. (2007) "Nigeria: Oil Smuggling and other Economic Troubles" Multinational monitor.org/hyper/issues/1984/05/turner.html

Auty, Richard (1993) Sustaining Development in

Agbah, Edorch (1997) "Petroleum in subsidiaries: illusion and realities", Central Bank of Nigeria Economics and Financial Review,vol.34,Dec.,Lagos.

Basedau, Mathias(2005) Context matter-Rethinking the Resource Curse in Sub-Saharan Africa, working Papers Global and Area Studies, working paper No.1,edited by the German overseas Institute(DUI),Hamburg.

Beblawi, Hazem (1987), The Rentier State in the Arab World, in Beblawi, $\mathrm{H}$ and Luciani,G(Cord): The Rentier State. New York: Croom Helm.

Beck, M (2007)Der Rentierstaats- An satz und das problem abweichender Fälle, in : Zeitschrift für international Beziekungen,14,1 pp.4370

Collier,Paul/Hoeffler,Anke(2001) Greed and Grievance in Civil war. Washington, DC: World Bank.

C.B.N (2009) Central Bank of Nigeria Annual Report and Statement of Accounts, CBN, Abuja.

De Soysa,Indra(2000) Are Civil wars driven by Rapacity or paucity? In: Berdal,M./Malone.(eds.):Greed and Grievance. Boulder:Lynne Rienner,pp.113-135.

Dunning, Thad(2008) Crude Democracy: Natural Resource Wealth and Political Regimes. New York: Cambridge University Press.

Duke,Edem(1995) "Understanding the petroleum sector of the Nigerian Economy" NAPETCOR,2nd Quarter,Lagos.

Edame, G.E. and Effiong, C.E.(2013) The Trend Analysis of Oil Revenue and Oil Export in Nigeria. IOSR Journal of Business and Management.Vol.10 Issue 3 May-June 2013. page 01-08.

Emenuga, C.(1993) "Nigeria: in search of Acceptable Revenue Allocation Formulae", proceedings of the Annual Conference of the Nigerian economic Society.

Eromosele,V.(1997) Nigerian petroleum Business-A handbook, Advert Communications Limited, Lagos, Nigeria.

http://data.un.org. United Nations data: A world of Information. 2012.

IMFsurvey(2004) Tackling the national resources curse: An illustration from Nigeria.IMF working paper No.03/139.IMF publication services, Box x2004,IMF,Washington,DC 20431,U.S.A.

Le Billon, Phillipe (2001)The political Ecology of war. Natural Resources and Armed conflict, political Geography 20, 5, pp.561-584.

Mahdavi, H. (1971) The Patterns and Problems of Economic development in rentier states, in: M.A.Cook (ed): studies in the Economic History of the Mddle East. London.

National Bureau of Statistics (2010) Review of the Nigerian Economy. Abuja: NBS.

Olashore, E. (1989) "The Risk of Management in Nigerian oil Industry", Lagos: NNPC Journal, vol.2.

Olomola, P. A. and Adyumo A. V. (2006) Oil Price shock and macroeconomic activities in Nigeria. In A. Adenikinju, A. Iwayemi E. W. lledare (Eds). Energy technology and infrastructure for development (Pp. 237-249). Ibadan: Atlantis Books.

Peters, A (2005) "The Niger Delta: 'Petro Violence' and "Partnership Development" Review of African Political Economy.

Ross, Micheal L.(2001) Does oil Hinder Democracy? in: World politics,53(April),pp.325-361.

Sachs, Jeffery D. \& Warner, Andrew M. (2001) The Curse of National Resourse. European Economic Review, Elsevier, vol.45,45,pp.827-838.

Sanusi, L.S. (2010) Growth prospects for the Nigerian Economy. Convocation lecture delivered at the Igbinedion University Eighth Convocation ceremony, Okada, Edo State, November 26, 2010. 